\title{
Multiple variants of TERT and CLPTM1L constitute risk factors for lung adenocarcinoma
}

\author{
X.F. Chen ${ }^{1 *}$, S. Cai ${ }^{2 *}$, Q.G. Chen ${ }^{2}$, Z.H. Ni ${ }^{2}$, J.H. Tang ${ }^{2}$, D.W. $\mathrm{Xu}^{3}$ and \\ X.B. Wang ${ }^{2}$ \\ ${ }^{1}$ Department of Thoracic Surgery, Shanghai Pulmonary Hospital, \\ Tongji University, Shanghai, China \\ ${ }^{2}$ Department of Respiratory Medicine, Putuo Hospital, \\ Shanghai University of Traditional Chinese Medicine, Shanghai, China \\ ${ }^{3}$ Hematology Laboratory, Center of Molecular Medicine, \\ Department of Medicine, Karolinska Institute, Stockholm, Sweden \\ *These authors contributed equally to this study. \\ Corresponding author: X.B. Wang \\ E-mail: xiongbiao6@yahoo.com
}

Genet. Mol. Res. 11 (1): 370-378 (2012)

Received January 4, 2011

Accepted November 26, 2011

Published February 16, 2012

DOI http://dx.doi.org/10.4238/2012.February. 16.2

ABSTRACT. Recent studies have shown that $5 \mathrm{p} 15.33$ is one of the
chromosomal regions that is most consistently altered in lung cancer;
common variants that are located in this region have been genotyped in
various populations. However, the genetic contribution of these variants
to carcinogenesis is relatively unknown. A clinic-based case-control
study in Shanghai was undertaken on 196 patients with lung cancer and
229 healthy individuals. TERT rs 2736100 and CLPTM1L rs 401681 and
rs 402710 were genotyped using the ABI TaqMan Allelic Discrimination
assay. For rs 2736100 , the G variant and the GG genotype were more
frequent, whereas the TT genotype was less frequent in patients with
lung adenocarcinoma than in controls. The CT genotype at rs 401681
was more common and the TT genotype was rare in patients, and the
differences were significant between lung adenocarcinoma patients and
controls. This was also true for rs 402710 . Moreover, the frequency of 
the GGCTCT haplotype was higher and the TTTTTT frequency was lower in patients, especially those with lung adenocarcinoma. Aberrant linkage disequilibrium among the three SNPs was found in patients with lung adenocarcinoma. We conclude that multiple variants at $5 \mathrm{p} 15.33$ contribute to susceptibility to lung adenocarcinoma.

Key words: TERT; CLPTM1L; Lung cancer; SNP; Lung adenocarcinoma

\section{INTRODUCTION}

The incidence of lung cancer has increased in recent decades and is now the number one cause of cancer mortality in China (Chen, 2009). The majority of patients are diagnosed at advanced stages. Twenty years ago in China, the most common histology was squamous cell carcinoma, followed by adenocarcinoma, small-cell cancer, large-cell cancer, and cancers not otherwise specified (NOS) (Sun, 1987). However, with the increased incidence of lung adenocarcinoma, the distribution of histological types has shifted and adenocarcinoma has become predominant, as is also seen in the USA (Stinchcombe and Socinski, 2009). The etiology of lung cancer is unknown, but the high percentage of smokers in the Chinese population and pollution combine to increase the risk (Molina et al., 2008; Gu et al., 2009; Helland and Brustugun, 2009). However, special attention should be paid to the genetic component of lung carcinogenesis.

Genetic studies of lung cancer have led to the discovery of hundreds of associated genes, such as those encoding p53, BRCA1, and serine/threonine kinase (Reguart et al., 2008; Sreeja et al., 2008; Strazisar et al., 2009), which can partly explain the genetic risk factors. Several lung cancer susceptibility loci have recently been identified in genome-wide association studies (Easton and Eeles, 2008; Thomas et al., 2008; Boezen, 2009; Caporaso et al., 2009; Landi et al., 2009; Chung et al., 2010; Hsiung et al., 2010). 5p15.33 was recently identified as a susceptibility region for lung cancer, and two known genes (telomerase reverse transcriptase [TERT] and palate transmembrane 1-like [CLPTM1L]) are located in this region. Association studies of several single-nucleotide polymorphisms (SNPs) in these two genes have further confirmed this finding (Kang et al., 2008; McKay et al., 2008; Jin et al., 2009; Rafnar et al., 2009; Zienolddiny et al., 2009; Hsiung et al., 2010; Wang et al., 2008, 2010). It has also been shown that these variants at the TERT-CLPTM1L loci are associated with other cancers (Yamamoto et al., 2007). As far as we know, there are no reports available about whether these common SNPs are just disease markers or whether they present functionally significant risk. For cancer, one allele polymorphism could potentially only explain less than $1 \%$ genetic risk. Beside functional study, genotype or haplotype analysis could supply some clues for their genetic contribution. In the present study, we compared the 5p15.33 (rs2736100, rs401681 and rs402710) genotypes and haplotypes in 196 patients with non-small-cell lung cancer and 229 healthy controls living in the Shanghai area of China.

\section{MATERIAL AND METHODS}

\section{Cancer case-control studies}

This study was a case-control analysis of lung cancer. Cancer-free controls (229) were recruited in the west of Shanghai, China, after a physical examination, in 2007-2009, and 
the eligible individuals were gender and age ( \pm 3 years) matched. The ethnic background of patients and controls was Han. The initial diagnosis of lung cancer was confirmed histologically within this period, and included adenocarcinoma, squamous cell carcinoma, small-cell carcinoma, and NOS. Large-cell carcinoma and adenosquamous carcinoma were the main constituents of the NOS category. The characteristics of the study population are summarized in Table 1. The Shanghai University of Traditional Chinese Medicine Ethics Committee for Scientific Research approved the study protocol, and written consent was obtained from all participants. The EDTA-blood samples were stored at $-20^{\circ} \mathrm{C}$ before genomic DNA isolation.

\begin{tabular}{|c|c|c|c|}
\hline Characteristics & $\begin{array}{c}\text { Controls } \\
(\mathrm{N}=229)\end{array}$ & $\begin{array}{c}\text { Cases } \\
(\mathrm{N}=196)\end{array}$ & $P$ value \\
\hline \multicolumn{4}{|l|}{$\overline{\text { Age }}$} \\
\hline Median age & 54.6 & 55.9 & \multirow[t]{2}{*}{0.926} \\
\hline Mean \pm SD & $54.6 \pm 10.2$ & $55.9 \pm 10.3$ & \\
\hline \multicolumn{4}{|l|}{ Gender } \\
\hline Male & 168 & 152 & \multirow[t]{2}{*}{0.318} \\
\hline Female & 61 & 44 & \\
\hline \multicolumn{4}{|l|}{ Smoking status } \\
\hline Nonsmoker & 119 & 73 & \multirow{2}{*}{0.002} \\
\hline Smoker & 110 & 123 & \\
\hline \multicolumn{4}{|l|}{ Histological cell type } \\
\hline Adenocarcinoma & & 96 & \\
\hline Squamous cell & & 44 & \\
\hline Small cell & & 16 & \\
\hline Other carcinoma & & 40 & \\
\hline
\end{tabular}

\section{SNP selection and DNA extraction}

The SNPs were selected from the National Center for Biotechnology Information (NCBI). The information on the SNPs is listed in Table 2. DNA was extracted using proteinase $\mathrm{K}$ digestion, followed by ethanol precipitation. DNA concentrations were measured with spectrophotometry. The DNA samples were stored at $-20^{\circ} \mathrm{C}$ until use.

\begin{tabular}{|c|c|c|c|c|c|}
\hline Gene & Rs No. & Location & $\begin{array}{l}\text { Gene } \\
\text { region }\end{array}$ & Mutation & Primers $\left(5^{\prime} \rightarrow 3^{\prime}\right)$ \\
\hline CLPTMIL & rs402710 & 1373733 & Exon 1 & $\mathrm{C} / \mathrm{T}$ & $\begin{array}{l}\text { F: GTGTGCTGTTTTCCCTGCTGACTTA } \\
\text { R: CCAGCAATAACAAGACAGAAGAACCAC } \\
\text { S: TTTTTTTTTTTTTTTATTGTTTTCCGTGTTGAGTGTTTCT }\end{array}$ \\
\hline & rs401681 & 1375087 & Intron & $\mathrm{C} / \mathrm{T}$ & $\begin{array}{l}\text { F: ACACACCGCCTTACCTTGTAGTTCA } \\
\text { R: TCGTAGACTCTTGATAAACTTACCAGC } \\
\text { S: TTTGAAAGCTGCTTCACACCATGAT }\end{array}$ \\
\hline TERT & rs 2736100 & 1339516 & Intron & $\mathrm{G} / \mathrm{T}$ & $\begin{array}{l}\text { F: GAAAAACCACCACCTGCAAATTATC } \\
\text { R: TTAGTTCCAAGCATCTGCCAAAAGC } \\
\text { S: TTTTTTTTTTTTTTTTTTTTTTTTTTTTACCTGCGGTGAGTGC }\end{array}$ \\
\hline
\end{tabular}

$\mathrm{F}=$ forward primer; $\mathrm{R}=$ reverse primer; $\mathrm{S}=$ sequencing primer.

\section{Genotyping}

All samples were genotyped with the TaqMan 7900HT Sequence Detection System, according to manufacturer instructions. The assays were carried out in 96-well 
plates and included six duplicate samples in each plate for quality control. The genotypes were determined using the Allelic Discrimination Sequence Detection Software (Applied Biosystems, USA). Each assay was performed using $1 \mathrm{ng}$ DNA in a $25-\mu \mathrm{L}$ reaction containing the TaqMan Universal PCR Master Mix (Applied Biosystems), forward and reverse primers, and FAM- and VIC-labeled probes designed by Applied Biosystems. The primers and probes used are listed in Table 2. The protocol followed was from the instruction manual from Applied Biosystems. Individual samples with failed sequencing wells were not repeated. Therefore, the numbers of samples successfully genotyped for each polymorphism varied.

\section{Statistical analysis}

Hardy-Weinberg equilibrium (HWE) was assessed using the goodness-of-fit $\chi^{2}$ test to compare the observed genotype frequencies with the expected genotype frequencies among the control subjects. The genotype and allele frequencies were calculated using the $\chi^{2}$ test $(2 \times 2$ contingency tables) and associations are expressed as odds ratios (ORs) with $95 \%$ confidence intervals $(95 \% \mathrm{CIs})$. The linkage disequilibrium between SNPs was estimated by calculating the delta values $(\Delta)$ based on the observed and expected haplotype frequencies (Svejgaard et al., 1975).

A value of $\mathrm{P} \leq 0.05$ was considered to be statistically significant.

\section{RESULTS}

The characteristics of patients with lung cancer are presented in Table 1. There was no difference in the gender distribution of the patients and controls, nor in their average ages; $37.2 \%$ of patients were nonsmokers, whereas $52 \%$ of controls were nonsmokers $(\mathrm{P}=0.002)$.

Three SNPs at these loci were genotyped in patients and controls (196 patients/229 controls). The allele frequencies of the three SNPs in the controls were consistent with HWE. The primary test of association was a comparison of the allele and genotype frequencies between the cases and controls. There were no differences in the frequencies between the controls and patients. When the patients were divided into subgroups according to their histopathology, the frequency of the G allele at rs2736100 was significantly increased in patients with lung adenocarcinoma compared with the frequency in healthy controls $(\mathrm{OR}=0.607$; $95 \% \mathrm{CI}=0.432-0.853 ; \mathrm{P}=0.004)$, but it was not relatively elevated in the other patients. No difference was observed in the frequencies of the other two SNPs between the different cancer subtypes and the control.

The distributions of the genotypes are summarized in Table 3. At rs 2736100 , the genotype GG was more frequent $(\mathrm{OR}=0.530,95 \% \mathrm{CI}=0.312-0.901, \mathrm{P}=0.018)$ and TT was less frequent $(\mathrm{OR}=2.004,95 \% \mathrm{CI}=1.105-3.634, \mathrm{P}=0.021)$ in patients with lung adenocarcinoma but not in the patients with other cancers. The patients with lung cancer carried the CT genotype more often at rs401681 (OR $=0.595,95 \% \mathrm{CI}=0.402-0.881, \mathrm{P}=0.009)$ and TT less often $(\mathrm{OR}=2.278,95 \% \mathrm{CI}=1.066-4.871, \mathrm{P}=0.030)$ than did the controls. When the patients were divided into subgroups, patients with adenocarcinoma accounted for the significant differences between the lung cancer group and controls. At rs402710, the genotype CT was more prevalent in patients with lung cancer $(\mathrm{OR}=0.608,95 \% \mathrm{CI}=0.410-0.903, \mathrm{P}=0.013)$. The 
Table 3. Comparative analysis of genotype frequencies and the risk of lung cancer in the subgroups.

\begin{tabular}{|c|c|c|c|c|c|c|c|}
\hline \multirow[t]{2}{*}{ SNP } & & \multirow{2}{*}{$\begin{array}{l}\text { Control } \\
\text { N (\%) }\end{array}$} & \multirow{2}{*}{$\begin{array}{l}\text { Cancer } \\
\mathrm{N}(\%)\end{array}$} & \multicolumn{4}{|c|}{ Histopathology } \\
\hline & & & & $\begin{array}{c}\text { Adenocarcinoma } \\
\text { N }(\%)\end{array}$ & $\begin{array}{c}\text { Squamous cell } \\
\mathrm{N}(\%)\end{array}$ & $\begin{array}{l}\text { Small cell } \\
\mathrm{N}(\%)\end{array}$ & $\begin{array}{l}\text { Others } \\
\mathrm{N}(\%)\end{array}$ \\
\hline \multirow[t]{2}{*}{ rs 402710} & $\mathrm{C}$ & $329(72.15)$ & $280(72.54)$ & $146(76.84)$ & $59(70.24)$ & $24(75.00)$ & $51(63.75)$ \\
\hline & $\mathrm{T}$ & $127(27.85)$ & $106(27.46)$ & $44(23.16)$ & $25(29.76)$ & $8(25.00)$ & $29(36.25)$ \\
\hline \multirow[t]{2}{*}{ rs401681 } & $\mathrm{C}$ & $329(72.15)$ & $280(71.79)$ & $144(75.00)$ & $62(72.09)$ & $24(75.00)$ & $50(62.50)$ \\
\hline & $\mathrm{T}$ & $127(27.85)$ & $110(28.21)$ & $48(25.00)$ & $24(27.91)$ & $8(25.00)$ & $30(37.50)$ \\
\hline \multirow[t]{2}{*}{ rs 2736100} & G & $208(45.41)$ & $201(51.28)$ & $111(57.81)^{\mathrm{a}}$ & $37(42.05)$ & $14(43.75)$ & $39(48.75)$ \\
\hline & $\mathrm{T}$ & $250(54.59)$ & $191(48.72)$ & $81(42.19)^{\mathrm{a}}$ & $51(57.95)$ & $18(56.25)$ & $41(51.25)$ \\
\hline \multicolumn{8}{|l|}{ Genotype } \\
\hline \multirow[t]{3}{*}{ rs 402710} & $\mathrm{CC}$ & $126(55.26)$ & $96(49.74)$ & $52(54.74)$ & $21(50.00)$ & $8(50.00)$ & $15(37.50)$ \\
\hline & $\mathrm{CT}$ & $77(33.77)$ & $88(45.60)^{\mathrm{b}}$ & $42(44.21)$ & $17(40.48)$ & $8(50.00)$ & $21(52.50)$ \\
\hline & TT & $25(10.96)$ & $9(4.66)^{c}$ & $1(1.05)^{d}$ & $4(9.52)$ & $0(0)$ & $4(10.00)$ \\
\hline \multirow{3}{*}{ rs401681 } & $\mathrm{CC}$ & $126(55.26)$ & $95(48.72)$ & $50(52.08)$ & $22(51.16)$ & $8(50.00)$ & $15(37.50)$ \\
\hline & CT & $77(33.77)$ & $90(46.15)^{\mathrm{e}}$ & $44(45.83)^{\mathrm{g}}$ & $18(41.86)$ & $8(50.00)$ & $20(50.00)$ \\
\hline & $\mathrm{TT}$ & $25(10.96)$ & $10(5.13)^{\mathrm{f}}$ & $2(2.08)^{\mathrm{h}}$ & $3(6.98)$ & $0(0)$ & $5(12.50)$ \\
\hline \multirow{3}{*}{ rs 2736100} & GG & $48(20.96)$ & $50(25.51)$ & $32(33.33)^{\mathrm{i}}$ & $7(15.91)$ & $2(12.50)$ & $9(22.50)$ \\
\hline & GT & $112(48.91)$ & $101(51.53)$ & $47(48.96)$ & $23(52.27)$ & $10(62.50)$ & $21(52.50)$ \\
\hline & TT & $69(30.13)$ & $45(22.96)$ & $17(17.71)^{\mathrm{j}}$ & $14(31.82)$ & $4(25.00)$ & $10(25.00)$ \\
\hline
\end{tabular}

${ }^{\mathrm{a}} \mathrm{P}=0.004, \mathrm{OR}=0.607,95 \% \mathrm{CI}=0.432-0.853 .{ }^{\mathrm{b}} \mathrm{P}=0.013, \mathrm{OR}=0.608,95 \% \mathrm{CI}=0.410-0.903 .{ }^{\mathrm{c}} \mathrm{P}=0.018, \mathrm{OR}=$ $2.518,95 \% \mathrm{CI}=1.145-5.534 .{ }^{\mathrm{d}} \mathrm{P}=0.003, \mathrm{OR}=11.576,95 \% \mathrm{CI}=1.545-86.717 .{ }^{\mathrm{e}} \mathrm{P}=0.009, \mathrm{OR}=0.595,95 \% \mathrm{CI}=$ $0.402-0.881 .{ }^{\mathrm{f}} \mathrm{P}=0.030, \mathrm{OR}=2.278,95 \% \mathrm{CI}=1.066-4.871 .{ }^{\mathrm{g}} \mathrm{P}=0.040, \mathrm{OR}=0.603,95 \% \mathrm{CI}=0.371-0.980 .{ }^{\mathrm{h}} \mathrm{P}=$ $0.008, \mathrm{OR}=5.788,95 \% \mathrm{CI}=1.343-24.946 .{ }^{\mathrm{P}} \mathrm{P}=0.018, \mathrm{OR}=0.530,95 \% \mathrm{CI}=0.312-0.901 .{ }^{.} \mathrm{P}=0.021, \mathrm{OR}=2.004$, $95 \% \mathrm{CI}=1.105-3.634$.

frequency of the TT genotype was lower in patients with lung cancer $(\mathrm{OR}=2.518,95 \% \mathrm{CI}=$ 1.145-5.534, $\mathrm{P}=0.018)$ and the lowest prevalence occurred in the patients with adenocarcinoma $(\mathrm{OR}=11.576,95 \% \mathrm{CI}=1.545-86.717, \mathrm{P}=0.003)$.

Because lung cancer is a heterogeneous disorder, the individual's genetic make-up is an important predisposing factor for developing the disease. There is no evidence to suggest that these three variants are themselves causative, so their contributions as risk factors for lung cancer were considered. Here, we also compared the distributions of the haplotypes in patients and controls. The three SNPs rs2736100, rs401681 and rs402710 were connected sequentially. The haplotype GGCTCT was more common in patients than in controls $(\mathrm{P}=0.035)$, whereas TTTTTT was less frequent in patients than in controls $(\mathrm{P}=0.040$; Table 4$)$, especially in patients with lung adenocarcinoma $(\mathrm{P}=0.005$ for GGCTCT and $\mathrm{P}=0.030$ for TTTTTT; Table 5). It seems that the $T$ allele is the protective allele in all three SNPs, whereas the $G$ allele in rs2736100 and the $\mathrm{C}$ allele in both rs401681 and rs402710 are risk factors. The combination of these risk factors may partly explain the susceptibility associated with $5 \mathrm{p} 15.33$. The two SNPs rs401681 and rs402710 are next to each other in the CLPTM1L gene and are strongly linked. The $\Delta$ value between rs 402710 and rs 401681 was 0.288 in controls. However, the linkage with rs 2736100 is relatively weaker (the $\Delta$ value between rs 2736100 and rs 402710 was 0.147 , and the $\Delta$ value between rs 2736100 and rs 401681 was 0.147 ). These linkages were reduced in the patient group, as reflected in lower $\Delta$ values $(0.192$ between rs 402710 and rs $401681 ; 0.093$ between rs 2736100 and rs402710, and 0.123 between rs 2736100 and rs401681). This aberrant linkage disequilibrium could be another risk factor in the genetic susceptibility to lung cancer.

All data have been analyzed in subgroups according to smokers and non-smokers. No significant difference has been found between these two groups (data not shown), which suggests that genetic susceptibility is the intrinsic carcinogenesis. 


\begin{tabular}{|c|c|c|c|c|c|c|c|}
\hline \multicolumn{3}{|c|}{ Haplotype } & \multirow{2}{*}{$\frac{\text { Control }}{\mathrm{N}(\%)}$} & \multirow{2}{*}{$\frac{\text { Lung cancer }}{\mathrm{N}(\%)}$} & \multirow[t]{2}{*}{$P$} & \multirow[t]{2}{*}{ OR } & \multirow[t]{2}{*}{$95 \% \mathrm{CI}$} \\
\hline rs 402710 & rs401681 & rs 2736100 & & & & & \\
\hline TT & TT & GG & $4(1.75)$ & $0(0.00)$ & 0.128 & & \\
\hline $\mathrm{CC}$ & $\mathrm{CC}$ & GG & $35(15.35)$ & $32(16.58)$ & 0.731 & 0.912 & $0.541-1.539$ \\
\hline $\mathrm{CT}$ & $\mathrm{CT}$ & GG & $8(3.51)$ & $16(8.29)$ & 0.035 & 0.402 & $0.168-0.962$ \\
\hline $\mathrm{CT}$ & $\mathrm{CC}$ & GG & $1(0.44)$ & $1(0.52)$ & 1.000 & 0.846 & $0.053-13.613$ \\
\hline TT & TT & GT & $6(2.63)$ & $4(2.07)$ & 0.957 & 1.277 & $0.355-4.593$ \\
\hline $\mathrm{CT}$ & TT & GT & $1(0.44)$ & $0(0.00)$ & 1.000 & & \\
\hline TT & $\mathrm{CT}$ & GT & $1(0.44)$ & $1(0.52)$ & 1.000 & 0.846 & $0.053-13.613$ \\
\hline $\mathrm{CC}$ & $\mathrm{CC}$ & GT & $64(28.07)$ & $41(21.24)$ & 0.107 & 1.447 & $0.923-2.269$ \\
\hline $\mathrm{CT}$ & $\mathrm{CT}$ & GT & $36(15.79)$ & $48(24.87)$ & 0.020 & 0.566 & $0.349-0.918$ \\
\hline $\mathrm{CC}$ & $\mathrm{CT}$ & GT & $2(0.88)$ & $3(1.55)$ & 0.664 & 0.560 & $0.093-3.389$ \\
\hline $\mathrm{CT}$ & $\mathrm{CC}$ & GT & $1(0.44)$ & $1(0.52)$ & 1.000 & 0.846 & $0.053-13.613$ \\
\hline TT & TT & TT & $14(6.14)$ & $4(2.07)$ & 0.040 & 3.091 & $1.000-9.553$ \\
\hline $\mathrm{CC}$ & $\mathrm{CC}$ & $\mathrm{TT}$ & $25(10.96)$ & $19(9.84)$ & 0.708 & 1.128 & $0.601-2.118$ \\
\hline $\mathrm{CT}$ & $\mathrm{CT}$ & TT & $30(13.16)$ & $20(10.36)$ & 0.377 & 1.311 & $0.718-2.392$ \\
\hline $\mathrm{CC}$ & $\mathrm{CT}$ & GG & $0(0.00)$ & $1(0.52)$ & 0.458 & & \\
\hline $\mathrm{CT}$ & TT & TT & $0(0.00)$ & $2(1.04)$ & 0.210 & & \\
\hline
\end{tabular}

Table 5. Comparative analysis of haplotype frequencies and the risk of lung adenocarcinoma.

\begin{tabular}{|c|c|c|c|c|c|c|c|}
\hline \multicolumn{3}{|c|}{ Haplotype } & \multirow{2}{*}{$\begin{array}{c}\text { Control } \\
\mathrm{N}(\%)\end{array}$} & \multirow{2}{*}{$\frac{\text { Adenocarcinoma }}{\mathrm{N}(\%)}$} & \multirow[t]{2}{*}{$\mathrm{P}$} & \multirow[t]{2}{*}{ OR } & \multirow[t]{2}{*}{$95 \% \mathrm{CI}$} \\
\hline rs 402710 & rs401681 & rs 2736100 & & & & & \\
\hline $\mathrm{TT}$ & TT & GG & $4(1.75)$ & $0(0.00)$ & 0.324 & & \\
\hline $\mathrm{CC}$ & $\mathrm{CC}$ & GG & $35(15.35)$ & $20(21.05)$ & 0.214 & 0.680 & $0.369-1.252$ \\
\hline $\mathrm{CT}$ & $\mathrm{CT}$ & GG & $8(3.51)$ & $11(11.58)$ & 0.005 & 0.278 & $0.108-0.714$ \\
\hline $\mathrm{CT}$ & $\mathrm{CC}$ & GG & $1(0.44)$ & $1(1.05)$ & 0.502 & 0.414 & $0.026-6.690$ \\
\hline TT & TT & GT & $6(2.63)$ & $1(1.05)$ & 0.678 & 2.541 & $0.302-21.393$ \\
\hline $\mathrm{CT}$ & $\mathrm{TT}$ & GT & $1(0.44)$ & $0(0.00)$ & 1.000 & & \\
\hline $\mathrm{TT}$ & $\mathrm{CT}$ & GT & $1(0.44)$ & $0(0.00)$ & 1.000 & & \\
\hline $\mathrm{CC}$ & $\mathrm{CC}$ & GT & $64(28.07)$ & $19(20.00)$ & 0.130 & 1.561 & $0.874-2.787$ \\
\hline $\mathrm{CT}$ & $\mathrm{CT}$ & GT & $36(15.79)$ & $23(24.21)$ & 0.074 & 0.587 & $0.326-1.058$ \\
\hline $\mathrm{CC}$ & $\mathrm{CT}$ & GT & $2(0.88)$ & $3(3.16)$ & 0.154 & 0.271 & $0.045-1.651$ \\
\hline $\mathrm{CT}$ & $\mathrm{CC}$ & GT & $1(0.44)$ & $0(0.00)$ & 1.000 & & \\
\hline TT & TT & TT & $14(6.14)$ & $0(0.00)$ & 0.030 & & \\
\hline $\mathrm{CC}$ & $\mathrm{CC}$ & TT & $25(10.96)$ & $10(10.53)$ & 0.908 & 1.047 & $0.482-2.274$ \\
\hline $\mathrm{CT}$ & $\mathrm{CT}$ & TT & $30(13.16)$ & $6(6.32)$ & 0.075 & 2.247 & $0.903-5.592$ \\
\hline $\mathrm{CT}$ & TT & TT & $0(0.00)$ & $1(1.05)$ & 0.294 & & \\
\hline
\end{tabular}

\section{DISCUSSION}

Consistent with published data, all three SNPs, rs2736100, rs401681, and rs402710, were associated with lung cancer, especially lung adenocarcinoma. The T nucleotide was protective in all three SNPs and the lack of the T nucleotide may be a risk factor for lung adenocarcinoma. The distributions of these genotypes and haplotypes indicate that a combined role of several SNPs better accounts for the association between region 5p15.33 and lung cancer, rather than a single allele. Genotype and haplotype analyses are important because the additive effects of these variants could constitute the genetic risk in this disease.

TERT is the reverse transcriptase catalytic subunit of telomerase. In most replicating eukaryotic cells, telomeres are synthesized and maintained by telomerase. TERT, the rate-limiting determinant of telomerase activity, is tightly repressed in most normal human cells, whereas it is highly expressed in many tumor tissues, including lung cancer (Nishio 
et al., 2007; Metzger et al., 2009). It has been established that TERT induction and telomerase activation are critical steps during cellular immortalization and transformation. High telomerase activity or TERT expression predicts disease progression and poor outcomes in patients with lung cancer (Fernandez-Garcia et al., 2008). When telomerase or TERT is inhibited, cancer cells undergo telomere shortening, senescence or apoptosis, and eventually lose their oncogenic potential. However, high TERT expression is not present in all histologies. Low levels of TERT mRNA are significantly associated with squamous cell histology (Metzger et al., 2009), whereas adenocarcinoma cells exhibit even higher TERT expression (Zhu et al., 2006). This difference may explain our data, in which a strong association was only observed between the TERT SNP and lung adenocarcinoma. The mutation from $\mathrm{T}$ to $\mathrm{C}$ at rs 2736100 may be associated with the upregulation of TERT expression in lung adenocarcinoma.

In squamous cell lung cancer, lower TERT or telomerase expression may lead to telomere dysfunction. The impact of telomere dysfunction on tumorigenesis depends upon the status of the tumor suppressor p53 (Maser et al., 2007). With abnormal p53 function, the loss of telomere function leads to cancer-relevant genomic changes (Perera et al., 2008). In the presence of functional p53, telomere dysfunction acts as a barrier to tumorigenesis through the elimination of cells by senescence and apoptotic processes. Numerous studies have shown that smoke exposure triggers p53 mutation. Therefore, it is likely that there are different requirements for TERT in the formation and development of these two types of lung cancer. Further studies are required to define the exact roles of the TERT SNPs, telomere dysfunction, and genomic instability in the pathogenesis of squamous cell lung cancer and adenocarcinoma.

CLPTM1L was identified among the genes involved in resistance to the anticancer drug cisplatin in ovarian cancer cells (Yamamoto et al., 2001). Yamamoto found that the expression of CLPTMIL was upregulated in all the cisplatin-resistant cell lines examined. The overexpression of $C L P T M 1 L$ in a cisplatin-sensitive cell line resulted in apoptosis, whereas $C L P T M 1 L$ overexpression had no effect on a cisplatin-resistant cell line. The gene is widely expressed in different tissues, including lung tissue. However, its protein structure and function are almost unknown. As far as we are aware, the functions of these two SNPs are totally unknown. The powerful genetic association of CLPTMIL with multiple cancers should encourage researchers to define this gene in detail.

\section{CONCLUSION}

Our study provides further evidence that $5 \mathrm{p} 15.33$ variants are associated with lung adenocarcinoma. Information from our haplotype analysis suggests that a combination of multiple variants underlies this susceptibility to lung cancer. Further studies are required, including a functional study and the identification of more variants in this region.

\section{ACKNOWLEDGMENTS}

Research supported by grants from the National Science Foundation of China (\#30872553) and the Shanghai Science and Technology Committee (\#08ZR1420900, \#09JC14412900, and \#10411969100). 


\section{REFERENCES}

Boezen HM (2009). Genome-wide association studies: what do they teach us about asthma and chronic obstructive pulmonary disease? Proc. Am. Thorac. Soc. 6: 701-703.

Caporaso N, Gu F, Chatterjee N, Sheng-Chih J, et al. (2009). Genome-wide and candidate gene association study of cigarette smoking behaviors. PLoS One 4: e4653.

Chen WQ (2009). Estimation of cancer incidence and mortality in China in 2004-2005. Zhonghua Zhong. Liu Za Zhi. 31: 664-668.

Chung CC, Magalhaes WC, Gonzalez-Bosquet J and Chanock SJ (2010). Genome-wide association studies in cancercurrent and future directions. Carcinogenesis 31: 111-120.

Easton DF and Eeles RA (2008). Genome-wide association studies in cancer. Human Mol. Genet. 17: R109-115.

Fernandez-Garcia I, Ortiz-de-Solorzano C and Montuenga LM (2008). Telomeres and telomerase in lung cancer. $J$. Thorac. Oncol. 3: 1085-1088.

Gu D, Kelly TN, Wu X, Chen J, et al. (2009). Mortality attributable to smoking in China. N. Engl. J. Med. 360: 150-159. Helland A and Brustugun OT (2009). Lung cancer in smokers and never-smokers. Tidsskr. Nor. Laegeforen. 129: 1859-1862.

Hsiung CA, Lan Q, Hong YC, Chen CJ, et al. (2010). The 5p15.33 locus is associated with risk of lung adenocarcinoma in never-smoking females in Asia. PLoS Genet. 6.

Jin G, Xu L, Shu Y, Tian T, et al. (2009). Common genetic variants on 5p15.33 contribute to risk of lung adenocarcinoma in a Chinese population. Carcinogenesis 30: 987-990.

Kang JU, Koo SH, Kwon KC, Park JW, et al. (2008). Gain at chromosomal region 5p15.33, containing TERT, is the most frequent genetic event in early stages of non-small cell lung cancer. Cancer Genet. Cytogenet. 182: 1-11.

Landi MT, Chatterjee N, Yu K, Goldin LR, et al. (2009). A genome-wide association study of lung cancer identifies a region of chromosome 5p15 associated with risk for adenocarcinoma. Am. J. Hum. Genet. 85: 679-691.

Maser RS, Choudhury B, Campbell PJ, Feng B, et al. (2007). Chromosomally unstable mouse tumours have genomic alterations similar to diverse human cancers. Nature 447: 966-971.

McKay JD, Hung RJ, Gaborieau V, Boffetta P, et al. (2008). Lung cancer susceptibility locus at 5p15.33. Nat. Genet. 40: 1404-1406.

Metzger R, Vallbohmer D, Muller-Tidow C, Higashi H, et al. (2009). Increased human telomerase reverse transcriptase (hTERT) mRNA expression but not telomerase activity is related to survival in curatively resected non-small cell lung cancer. Anticancer Res. 29: 1157-1162.

Molina JR, Yang P, Cassivi SD, Schild SE, et al. (2008). Non-small cell lung cancer: epidemiology, risk factors, treatment, and survivorship. Mayo Clin. Proc. 83: 584-594.

Nishio Y, Nakanishi K, Ozeki Y, Jiang SX, et al. (2007). Telomere length, telomerase activity, and expressions of human telomerase mRNA component (hTERC) and human telomerase reverse transcriptase (hTERT) mRNA in pulmonary neuroendocrine tumors. Jpn. J. Clin. Oncol. 37: 16-22.

Perera SA, Maser RS, Xia H, McNamara K, et al. (2008). Telomere dysfunction promotes genome instability and metastatic potential in a K-ras p53 mouse model of lung cancer. Carcinogenesis 29: 747-753.

Rafnar T, Sulem P, Stacey SN, Geller F, et al. (2009). Sequence variants at the TERT-CLPTM1L locus associate with many cancer types. Nat. Genet. 41: 221-227.

Reguart N, Cardona AF, Carrasco E, Gomez P, et al. (2008). BRCA1: a new genomic marker for non-small-cell lung cancer. Clin. Lung Cancer 9: 331-339.

Sreeja L, Syamala V, Raveendran PB, Santhi S, et al. (2008). p53 Arg72Pro polymorphism predicts survival outcome in lung cancer patients in Indian population. Cancer Invest. 26: 41-46.

Stinchcombe TE and Socinski MA (2009). Current treatments for advanced stage non-small cell lung cancer. Proc. Am. Thorac. Soc. 6: 233-241.

Strazisar M, Mlakar V, Rott T and Glavac D (2009). Somatic alterations of the serine/threonine kinase LKB1 gene in squamous cell (SCC) and large cell (LCC) lung carcinoma. Cancer Invest. 27: 407-416.

Sun Y (1987). The epidemiology, etiology and carcinogenesis of lung cancer. Beijing Med. 10: 56.

Svejgaard A, Hauge M, Jersild C, Platz P, et al. (1975). The HLA system. An introductory survey. Monogr. Hum. Genet. 7: 1-100.

Thomas G, Jacobs KB, Yeager M, Kraft P, et al. (2008). Multiple loci identified in a genome-wide association study of prostate cancer. Nat. Genet. 40: 310-315.

Wang Y, Broderick P, Webb E, Wu X, et al. (2008). Common 5p15.33 and 6p21.33 variants influence lung cancer risk. Nat. Genet. 40: 1407-1409.

Wang Y, Broderick P, Matakidou A, Eisen T, et al. (2010). Role of 5p15.33 (TERT-CLPTM1L), 6p21.33 and 15q25.1 
(CHRNA5-CHRNA3) variation and lung cancer risk in never-smokers. Carcinogenesis 31: 234-238.

Yamamoto K, Okamoto A, Isonishi S, Ochiai K, et al. (2001). A novel gene, CRR9, which was up-regulated in CDDPresistant ovarian tumor cell line, was associated with apoptosis. Biochem. Biophys. Res. Commun. 280: 1148-1154.

Yamamoto Y, Chochi Y, Matsuyama H, Eguchi S, et al. (2007). Gain of 5p15.33 is associated with progression of bladder cancer. Oncology 72: 132-138.

Zhu CQ, Cutz JC, Liu N, Lau D, et al. (2006). Amplification of telomerase (hTERT) gene is a poor prognostic marker in non-small-cell lung cancer. Br. J. Cancer 94: 1452-1459.

Zienolddiny S, Skaug V, Landvik NE, Ryberg D, et al. (2009). The TERT-CLPTM1L lung cancer susceptibility variant associates with higher DNA adduct formation in the lung. Carcinogenesis 30: 1368-1371. 